\title{
Pre-service Teachers' Readiness for Emergency Remote Learning in the Wake of COVID-19
}

\author{
Philip Dorsah 1*
}

${ }^{1}$ Gambaga College of Education, GHANA

*Corresponding Author:pdorsah@gmail.com

Citation: Dorsah, P. (2021). Pre-service Teachers' Readiness for Emergency Remote Learning in the Wake of COVID-19. European Journal of STEM Education, 6(1), 01. https:// doi.org/10.20897/ ejsteme/9557

Published: January 15, 2021

\begin{abstract}
The purpose of the study was to determine pre-service student teachers' readiness for emergency remote learning. The study participants consisted of 115 (66 males and 49 females) pre-service teachers of Gambaga College of Education, Ghana. Online learning readiness scale (OLRS) questionnaire was used to collect the data. Pre-service teachers were ready for online learning with overall readiness mean score of 3.65. The dimension with the highest mean score was motivation for learning $(\mathrm{M}=3.97, \mathrm{SD}=.90)$ followed by selfdirected learning $(\mathrm{M}=3.82, \mathrm{SD}=.93)$. However, the dimensions of learner control $(\mathrm{M}=3.30, \mathrm{SD}=1.00)$, computer/internet self-efficacy $(\mathrm{M}=3.43, \mathrm{SD}=1.16)$ and online communication self-efficacy $(\mathrm{M}=3.47$, $\mathrm{SD}=1.11)$ recorded low means. There was no significant difference in online learning readiness between males $(\mathrm{M}=3.71, \mathrm{SD}=.82)$ and females $(\mathrm{M}=3.57, \mathrm{SD}=.76), \mathrm{t}(.94), \mathrm{p}=.349$. Also, there was no significant difference in readiness between level 100 pre-service teachers $(\mathrm{M}=3.65, \mathrm{SD}=.79)$ and level 200 pre-service teachers $(\mathrm{M}=3.68, \mathrm{SD}=.85) \mathrm{t}(-.122), \mathrm{p}=.903$.
\end{abstract}

Keywords: pre-service teachers, COVID-19, online learning readiness, emergency remote teaching

\section{INTRODUCTION}

Rapid migration of schools to online learning due to COVID-19 pandemic has raised concerns at local and international levels about the quality of education and students' readiness to cope with the new emerging situation. The demand for high level of science and technological literacy makes Science, Technology, Engineering and Mathematics (STEM) education of high concern especially in these times. According to Lee and Campbell (2020), now is the time to create "a new normal" for science education specifically and STEM education broadly.

Students" preparedness to execute within an online educational context is very vital (Budzar, Ali \& Tariq, 2016). The need to understand students' readiness for online learning is more significant than ever because online learning is becoming popular in educational environments across the world due to lockdown of schools and universities because of COVID-19 pandemic. This situation forced all levels of educational institutions to operate remotely and to put emergency remote teaching into practice (Bozkurt \& Sharma, 2020). According to Dhawan (2020), betwixt the lockdown challenges, online teaching and online learning can be termed as the panacea for the crisis. Many academic institutions have shifted entirely to online teaching and learning (Dhawan, 2020).

Online learning can be defined as acquiring knowledge and skills through synchronous and asynchronous learning applications (Morrison, 2003). Distance education is characterized by the distance in time and/or space between learners and learning resources (Bozkurt \& Sharma, 2020). According to Chuck et al. (as cited in Bozkurt \& Sharma, 2020), what is currently being done is emergency remote teaching, which is considered a temporary solution to an immediate problem. 
According to Hung et al. (2010) students should be more active in online learning environments and should be more responsible in their learning, time-management, keeping up with the class, completing work on time and they should be active contributors to instruction. Aydin and Tasci posited that understanding students' readiness for online learning is the first step for developing and implementing an effective online learning system (as cited in Cigdem, \& Yildirim, 2014).

According to Conley (2007), readiness for university education can be defined as the level of preparation a student needs in order to enroll and succeed, without remediation in a credit-bearing program at higher education institution. E-learning readiness is defined as the degree to which learners are ready to take courses in online learning environment (Alem, Plaisent, Zuccaro \& Bernard, 2016). Research has shown that students who succeed in an online learning environment seem to have some academic preparation characteristics such as self-directed learning, self-competence, motivation, self-discipline and learning style (Morris, Wu \& Finnegan, 2005). Researchers also point out that students who are successful in the online environment are those who are well prepared and ready to follow their study online, skilled in the use of technology and browsing the Internet, and able to learn autonomously (Alem et al. 2016). Teachers can create a more suitable autonomous learning environment only if students' readiness and learner autonomy is known (Kartal \& Balcikanlh, 2019).

STEM has made it possible for online platforms to be created. The internet is the main driving force for remote learning, without STEM, there would be no internet and no possibilities for online learning. Again, without a basic understanding of STEM, a readiness for remote learning is impossible.

\section{PROBLEM}

Online learning can be challenging for students because of the self-regulated nature of learning online and the distance between instructors and students. Online courses provide learners with a variety of benefits such as convenience, flexibility, and opportunities to work collaboratively and closely with teachers and other students from different schools or even across the world (Hung et al. 2010). But are college students ready for online learning? The transition from traditional face-to-face environment to a fully virtual one can be challenging, and students need to be aware of what the differences and expectations are for their new learning platforms (Potts \& Potts, 2017). Harrell stated that previous research has identified five broad categories of factors that affect student success in online learning. These are student readiness, orientation, instructor effect through preparation and support and course content (as cited in Basol, Cigdem, \& Unver, 2018). Student online learning readiness has been identified as being closely associated with the success of learning in online environments (Liu, 2019). According to Liu and Roberts-Kaye (2016), online learning readiness is defined as "cognitive awareness and maturity that a student develops for successful learning in a Web-based environment. It manifests in the attributes of recognizing the self-directed nature, formulating learning strategies, obtaining technology competencies, adjusting to digital etiquettes, and being open for help-seeking” p. 242 (as cited in Liu, 2019). Several studies such as Mosa, Mahrin, \& Ibrrahim (2016) and Yilmaz (2017) have found that students' online learning readiness affects their academic achievement (as cited in Liu, 2019).

Bearing in mind that pre-service teachers' readiness for online learning might influence their cognitions and actions regarding the emergency remote online learning, it is essential to understand their online learning readiness. Researchers believe that supporting student success in learning has been the core value of education, regardless of formats (Liu, 2019).

Knowledge of student's readiness is very important since it will give teachers knowledge of learners and help them to guide students toward successful and fruitful online learning experiences. Teachers may need to help students develop self-directed learning and learner-control skills and attitudes, especially for online learning contexts (Hung et al., 2010). Again, teachers may need to improve the clarity of their syllabus and course structure before students can direct themselves toward taking full control of their own learning. Thus, teachers can help students to establish their own time- and information-management skills. Therefore, in this research, learners' online learning readiness was investigated within the dimensions proposed by Hung et al (2010). These are computer/Internet self-efficacy, learner control, motivation for learning, online communication self-efficacy and self-directed learning.

\section{Research Questions}

1. What is pre-service teachers' online learning readiness?

2. Is there any significant difference in online learning readiness between males and females?

3. Is there any significant difference in online learning readiness by course level? 


\section{LITERATURE REVIEW}

Learner readiness is often used to define the ability of a learner to acquire knowledge and initiate in behavior change which lead to effective and successful learning outcomes. It suggests that for learners to benefit from educational interventions at school, they must be constantly and always ready and at their fullest potential to learn (Chorrojprasert, 2020).

Readiness for online learning means the preparedness of students to perform learning activities in an online environment. It indicates multiple dimensions, including but not limited to comfort in learning with computers, self-regulated learning strategies, and perception of learning community (Liu, 2019). Students' readiness for elearning is viewed as connected with their capabilities to use technology for academic purposes.

Warner, Christie, and Choy (1998) defined readiness for online learning as a combination of students' preferences for online delivery, their competence and confidence in using electronic communication, and their ability to engage in autonomous learning. Lynch (2001) and Smith, Murphy, and Mahoney (2003) equate readiness for online learning with "comfort with e-learning" and "self-management of learning."

It has been reported that dominant constructs relating to learner readiness include: a desire to learn; a positive attitude toward the learning situation; a willingness to make the investment of time and effort that is necessary for learning, the ability to persevere, and an understanding of the importance and value of learning (Chorrojprasert, 2020).

Deyo, Huynh, Rochester, Sturpe and Kiser (2011) stated that learning readiness is essential for better educational performance of the students in learning process (as cited in Dangol \& Shrestha, 2019). Every effort to provide quality education in school becomes meaningless due to the absence of student readiness in learning. If the student is prepared to learn, he/she can learn rapidly and if the student is not geared up to learn, he/she cannot learn successfully (Prakash, 2012). Absence of learning readiness leads to decrease the educational achievement of students. It also decreases the efficiency and effectiveness of classroom teaching and also wastes huge government investment in the school education (Dangol \& Shrestha, 2019). According to Gandhi, learning readiness is the prerequisite for getting success to achieve the goals and objectives of education within students (as cited in Dangol \& Shrestha, 2019). Online learning readiness is related to student motivation and academic achievement. Cigdem and Ozturk (2016) stated that self-direction in online learning could strongly predict student achievement (as cited in Liu, 2019). Also Horzum, Kaymak, and Gungoren (2015) concluded that student online learning readiness could predict motivation and perception of academic achievement.

According to Chorrojprasert (2020), there are four characteristics that a learner should possess in order to learn effectively, particularly in classroom setting. These are a disposition for learning, adequate cognitive functioning, adequate knowledge base for the content being presented and adequate study skills and strategies.

A number of concepts have been used for learner readiness among which are learner autonomy, self-efficacy, self-regulation or self-directed learning, responsible learning, learner's attitudes and beliefs, learner's intellectual character and learning strategies (Chorrojprasert, 2020). Learner readiness is the process in which learners are able to actively and effectively control and monitor their motivation, cognition and behaviors and successfully complete the target academic tasks (Blidi, 2017).

Students who own their learning can go beyond simply following teacher directions. They are more likely to complete complex assignments, solve problems that require persistence, and create original or novel work of high quality (Conley \& French, 2013).

Hung, Chou, Chen, and Own (2010) presented a concept that claims that besides the computer/internet and online communication self-efficacies; students' readiness for e-learning is depicted in their potential for selfdirected learning, learner control, and motivation for learning.

Motivation for learning encompasses learners' all kinds of movements towards and engagements with learning activities. According to Wolters (2010), the primary factor that facilitates students' persistence in their academic tasks is their motivational beliefs. Motivated learners are attributed to have low latency and high perseverance about task engagement (Artino \& Stephens, 2009), and therefore, their motivational orientation towards a task has significant influences on their performances (Hung et al. 2010).

Motivation and engagement are closely related. Motivation is an internal state, while engagement is the manifestation of motivation behaviorally. Research proved that student engagement leads to higher achievement in the classroom (Conley \& French, 2013). Motivation and engagement factors involve students' ability to see the value in coursework, motivate to excel, see the value of learning, and enjoy a challenge. These skills are particularly important in a college setting where students are required to manage their own time and take responsibility for their own learning. Engagement is thought of as comprising three components: behavioral engagement (compliance with norms and expectations), emotional engagement (interest, enjoyment), and cognitive engagement (investment in learning, challenge-seeking) (Conley \& French, 2013). Motivation must manifest itself in the 
potential for self-guided action, and students must be both emotionally and cognitively engaged to succeed (Conley, 2007).

\section{THEORETICAL FRAMEWORK}

The study is based on Bandura's self-efficacy theory (Bandura, 1977). Bandura (1997) defines self-efficacy as "beliefs in one's capabilities to organize and execute the courses of action required to produce given attainments" (p. 3). Self-efficacy is a key contributing factor to learners' success because self-efficacy "influences the choices learners make and the courses of action they pursue" (Pajares, 2002, p. 116). Self-efficacy is not only a good predictor of learners' academic outcomes, but efficacious learners also tend to adapt, persist, and cope well, even when they have little prior online experience (Swan, 2004).

Readiness for online learning means the preparedness of students to perform learning activities in an online environment. It indicates multiple dimensions, including but not limited to comfort in learning with computers, self-regulated learning strategies, and perception of learning community (Liu, 2019). Borotis and Poulymenakou (2004) defined online readiness as "being mentally and physically ready for certain online learning experience and actions". Warner, Christie and Choy (1998) describe online learning readiness of students in three major aspects: preferences for online learning as opposed to face-to-face learning instructions, capability and confidence in using the technological tools and ability to learn independently. Hung et al. (2010) included sub-dimensions of "selfdirected learning, learner control, motivation, computer/internet self-efficacy towards learning and online communications self-efficacy" to measure online learning readiness. According to Engin (2017), a consideration of the sub-dimensions of online readiness revealed aspects such as self-confidence, self-knowledge, self-control, to communicate and self-expression.

Knowles (1975), defined self-directed learning as a process in which individuals take the initiative in understanding their learning needs, establishing learning goals, identifying human and material resources for learning, choosing and implementing appropriate learning strategies, and evaluating learning outcomes. Students' motivational orientation (intrinsic or extrinsic) has significant effects on their learning performance (Hung et al., 2010). According to Ryan and Deci (2000), intrinsic motivation is a critical element in cognitive, social, and physical development because it is through acting on one's inherent interests that one grows in knowledge and skills. Internet self-efficacy is defined as the trust Internet users have in them while using Internet. Internet self-efficacy could be different from computer self-efficacy in setting up, maintaining, and using the Internet behavior series (Hung et al., 2010). Tsai and Tsai (2003) showed that students with high Internet self-efficacy learned better than those with low Internet self-efficacy in a Web-based learning task. Online learning may also involve computermediated communication.

The concept of learner control was previously employed in the classroom to enhance the learning process by allowing learners to choose the way they learnt, or how they expressed what they had learnt. This concept was later implemented with technology-assisted instruction (Taipjutorus, Hansen, \& Brown, 2012). According to Milheim and Martin (1991), the nature of online learning makes it possible to provide learners with the opportunity to make their own choices and put them in charge of their learning pace, sequence, and content.

\section{METHODOLOGY}

\section{Design}

A cross-sectional survey design was adopted for the study using a quantitative approach. A cross-sectional survey collects data to make inferences about a population of interest at one point in time. Cross-sectional surveys have been described as snapshots of the populations about which they gather data (Hall, 2008). Quantitative research methods primarily rely on the collection and analyses of numerical data in the study of social phenomena (Leung \& Shek, 2018). Sharing the characteristics of positivism, quantitative research design has several unique features. These include: the quality assurance that bias and subjectivity are minimized in data collection and analyses, Value neutrality in the research, the research is guided by evidence obtained from systematic research rather than by authorities, and accuracy and precision of measurements determined by ensuring reliability and validity of research (Leung \& Shek, 2018).

\section{Participants and sampling}

The study participants consisted of 115 (66 males and 49 females) pre-service teachers of which 106 are in level 100 and 9 are in level 200. All the participants were on remote learning as a result of lockdown due to COVID-19. 
Convenience sampling was used to identify participants. All participants participated in synchronous and asynchronous online learning on Google classroom platform.

\section{Data collection}

The data were collected through an online questionnaire. The online learning readiness scale (OLRS) questionnaire was used to collect the data. The questionnaire was in two sections; the first section required participants to indicate their age, sex, and course level and the second section required them to indicate their level of agreement or disagreements to the 18 items of the OLRS. The 18 items measure online learning readiness on a five-point Likert type scale ( $1=$ strongly disagree, $2=$ Disagree, $3=$ Undecided, $4=$ Agree, $5=$ strongly agree).

\section{Instrument}

The Online Learning Readiness Scale (OLRS) is a multidimensional instrument developed by Hung, Chou, Chen, and Own (2010) to measure college students' readiness for online learning in Taiwan. The Online Learning Readiness Scale (OLRS) was validated in five dimensions: self-directed learning (SDL), motivation for learning (ML), computer/Internet self-efficacy (CIS), learner control (LC), and online communication self-efficacy (OCS) [Hung et al., 2010].

Self-directed learning dimension is about learners taking responsibility for their learning to reach their learning objectives. Learner control is how online learners take control over their learning such as repeating or skipping some content and on efforts by online learners to direct their own learning with maximum freedom. Motivation for learning centers on online learners' learning attitudes. Computer/Internet self-efficacy is about online learners' ability to demonstrate proper computer and Internet skills. Online communication self-efficacy describes learners' adaptability to the online setting through questioning, responding, commenting, and discussing (Hung et al, 2010). Hung et al (2010) subjected the scale through confirmatory factor analysis to determine the validity of the OLRS. Each item of the OLRS had a substantial loading between 0.55 and 0.85 on the five factors, and each loading was statistically significant. Thus, the scale constitutes a valid instrument for measuring learner readiness in online learning settings (Hung et al., 2010). In this present study, the reliability of the OLRS was determined to be .900. The reliabilities of the various dimensions were also determined as follows; CIS $=.749$, SDL $=.778, \mathrm{LC}=.618$, $\mathrm{ML}=.772$ and $\mathrm{OCS}=.743$.

\section{ONLINE LEARNING READINESS (OLR) SURVEYS}

From the literature, existing surveys on students' online readiness focused on learner characteristics such as self-directed learning, interpersonal communication skills, and academic locus of control, and basic technology skills such as email, word processing, and basic software (Dray, Lowenthal, Miszkiewicz, Ruiz-Primo, \& Marczynski 2011). According to Dray et al., readiness as expressed by these instruments encompasses; selfconcept/self-efficacy with academics, information, technology, and locus of control and equipment owned (e.g., computers). Most instruments that measure online learning readiness focus on technology preparation and independent study strategies for students (Liu, 2019).

According to Guglielmino and Guglielmino (2003), online learning readiness can be determined by evaluating a user's competency in using technological tools. McVay (2001) developed a 13-item instrument for measuring readiness for online learning which focused on student behavior and attitudes. Smith et al. (2003) conducted an exploratory study to test McVay's Readiness for Online Learning questionnaire. The instrument yielded a twofactor structure, "Comfort with e-learning" and "Self-management of learning."

Hung et al. (2010) added new dimensions to the readiness concept which include computer/Internet selfefficacy, learner control, motivation for learning, online communication self-efficacy and self-directed learning. Computer/Internet self-efficacy is related to technical skills involving computers and the Internet (Keramati, Afshari-Mofrad, Kamrani, 2011; Peng, Tsai, \& Wu, 2006). Learner control is related to flexibility and freedom in web-based study materials. Learner control is the degree to which a learner can direct his or her own learning experience and process (Shyu \& Brown, 1992). Online communication self-efficacy is related to computermediated communication. Self-directed learning is related to students' ability to direct his or her own learning through the appropriate knowledge, skills, attitudes and habits. According to Tang \& Lim (2013), online learning readiness can be described in three major features: choices for online learning as opposed to face-to-face learning instructions, competence and confidence in using the technological tools and ability to learn separately.

Warner, Christie, and Choy (1998) defined readiness for online learning in terms of three aspects: (1) students' preferences for the form of delivery as opposed to face-to-face classroom instruction; (2) student confidence in using electronic communication for learning and, in particular, competence and confidence in the use of Internet and computer-mediated communication; and (3) ability to engage in autonomous learning. 
Based on previous conceptualization, Dray et al. (2011) developed a survey that consisted of two subscales: learner characteristics and technology capabilities. The learner characteristics subscale asks about individual beliefs in their ability to complete a college degree, beliefs about responsibility in problem solving (academic and technical), self-efficacy in writing and expression, orientation to time and time management, and behavior regulation for goal attainment. The second subscale measures technology capabilities which include; basic technology skills such as the ability to use email and the internet, material access to technology such as devices and bandwidth, and the nature and frequency of technology use.

\section{ONLINE LEARNING}

According to Moore, Dickson-Deane, and Galyen (2011), the concept of online learning is difficult to define; however, there are numerous concepts that are considered synonymous with to the concept such as online course, web-based learning, distance learning, and web-based training (Edwards, 2018). One common definition of online learning is an educational training program via internet and computer-based media technologies (Sangrà, Vlachopoulos, Cabrera, \& Bravo, 2011). Another definition of online learning states it as distance education, involving students making use of web-based communication systems for interaction (via telecommunication and social media-based technologies). Through these technologies, individuals exchange information and communicate with their educators and fellow classmates (Sangrà, Vlachopoulos, Cabrera, \& Bravo, 2011). Various terms are used for online learning such as e-learning, distance learning, distance education, computer-assisted instruction, computer-based instruction, technology based-instruction, technology-delivered instruction, computer-based simulation and simulation games (Bell \& Federman, 2013).

Online learning or more commonly noted as e-learning or distance learning, is defined as learning facilitated virtually through an online interface system via computer, database, social media, network, and web technologies (Garrison, 2011). Another definition of online learning states it as distance education, involving students making use of web-based communication systems for interaction (via telecommunication and social media-based technologies). Through these technologies, individuals exchange information and communicate with their educators and fellow classmates (Sangrà, Vlachopoulos, Cabrera, \& Bravo, 2011). Another description of online learning refers to it as a system of learning and teaching, involving the use of internet technologies and multimedia in order to facilitate quality learning and enable access to various educational services and resources (Sangrà, Vlachopoulos, Cabrera, \& Bravo, 2011).

\section{RESULTS}

\section{Demographic characteristics of participants}

Table 1. Sex and Age distribution of participants

\begin{tabular}{lcc}
\hline Sex & $\mathbf{n}$ & $\mathbf{0}$ \\
\hline Male & 66 & 57 \\
Female & 49 & 43 \\
Total & $\mathbf{1 1 5}$ & $\mathbf{1 0 0}$ \\
\hline Age & & \\
\hline $18--20$ & 16 & 13.9 \\
$21--24$ & 58 & 50.4 \\
$25--28$ & 37 & 32.2 \\
$29--31$ & 4 & 3.5 \\
\hline Total & $\mathbf{1 1 5}$ & $\mathbf{1 0 0}$ \\
\hline
\end{tabular}

Table 1 shows the sex and age of participants of the study. The sex of participants comprised 66 males representing 57\% and 49 females representing 43\%. The ages of participants ranged from 18 to 31. Sixteen of them $(13.9 \%)$ aged between 18 to 20 years, fifty eight of them $(50.4 \%)$ aged between 21 to 24 years, thirty seven of them (32.2\%) aged between 25 to 28 years and four of them (3.5\%) aged between 29 to 31 years. 


\section{PRE-SERVICE TEACHERS' ONLINE LEARNING READINESS}

Table 2. Means and standard deviations of scores OLRS and its dimensions

\begin{tabular}{lcc}
\hline Dimensions & Mean & SD \\
\hline Online Learning Readiness score (OLRS) & 3.65 & 0.79 \\
Computer/Internet Self-efficacy (CIS) & 3.43 & 1.16 \\
Self-Directed Learning (SDL) & 3.82 & 0.93 \\
Learner Control (LC) & 3.30 & 1.00 \\
Motivation for Learning (ML) & 3.97 & 0.90 \\
Online communication self-efficacy (OCS) & 3.49 & 1.11 \\
\hline $\mathbf{N}=\mathbf{1 1 5}$ &
\end{tabular}

Table 2 shows the means and standard deviations of online learning readiness scores of the overall scale and the five dimensions. The overall mean score of the OLRS was 3.65 suggesting that on the average pre-service teachers are ready for online learning. The mean scores for the dimensions are as follows; computer/internet selfefficacy $(\mathrm{M}=3.43, \mathrm{SD}=1.16)$, self-directed learning $(\mathrm{M}=3.82$, $\mathrm{SD}=.93)$, learner control $(\mathrm{M}=3.30, \mathrm{SD}=1.00)$, motivation for learning $(\mathrm{M}=3.97, \mathrm{SD}=.90)$. The dimension with the highest mean score is motivation for learning $(\mathrm{M}=3.97, \mathrm{SD}=.90)$ followed by self-directed learning $(\mathrm{M}=3.82, \mathrm{SD}=.93)$. This suggests that pre-service teachers are motivated for online learning. Also, pre-service teachers are self-directed for online learning. However, the dimensions of learner control $(M=3.30, S D=1.00)$, computer/internet self-efficacy $(M=3.43, S D=1.16)$ and online communication self-efficacy $(\mathrm{M}=3.47, \mathrm{SD}=1.11)$ recorded low means. This suggests that pre-service teachers are not in control of their learning and their computer/internet and online communication self-efficacies are low.

Table 3. Descriptive statistics of items of the OLRS

\begin{tabular}{|c|c|c|c|c|}
\hline Item & Statement & Mean & SD & Rank \\
\hline 1 & $\begin{array}{l}\text { I feel confident in performing the basic functions of Microsoft Office programs (MS Word, MS Excel, } \\
\text { and MS PowerPoint) }\end{array}$ & 3.34 & 1.40 & 17 \\
\hline 2 & I feel confident in my knowledge and skills of how to manage software for online learning. & 3.38 & 1.39 & 14 \\
\hline 3 & I feel confident in using the Internet (Google, Yahoo) to find or gather information for online learning & 3.58 & 1.48 & 11 \\
\hline 4 & I carry out my own study plan. & 3.73 & 1.28 & 9 \\
\hline 5 & I seek assistance when facing learning problems. & 3.94 & 1.31 & 4 \\
\hline 6 & I manage time well. & 3.41 & 1.34 & 13 \\
\hline 7 & I set up my learning goals & 3.91 & 1.26 & 6 \\
\hline 8 & I have higher expectations for my learning performance. & 4.10 & 1.22 & 2 \\
\hline 9 & I can direct my own learning progress. & 3.73 & 1.29 & 8 \\
\hline 10 & I am not distracted by other online activities when learning online (instant messages, Internet surfing). & 2.80 & 1.48 & 18 \\
\hline 11 & I repeated the online instructional materials on the basis of my needs. & 3.36 & 1.22 & 15 \\
\hline 12 & I am open to new ideas. & 3.90 & 1.30 & 7 \\
\hline 13 & I have motivation to learn. & 3.92 & 1.21 & 5 \\
\hline 14 & I improve from my mistakes. & 4.11 & 1.07 & 1 \\
\hline 15 & I like to share my ideas with others. & 3.97 & 1.10 & 3 \\
\hline 16 & I feel confident in using online tools (email, discussion) to effectively communicate with others. & 3.34 & 1.43 & 16 \\
\hline 17 & I feel confident in expressing myself (emotions and humor) through text. & 3.63 & 1.29 & 10 \\
\hline 18 & I feel confident in posting questions in online discussions & 3.50 & 1.35 & 12 \\
\hline
\end{tabular}

$\mathbf{N}=115$

Table 3 shows the descriptive statistics of items of the OLRS and Figure 1 gives a graphical presentation of the mean scores of items of the OLRS. The items with the highest means are item14 (I improve from my mistakes), item 8 (I have higher expectations for my learning performance), item 15 (I like to share my ideas with others), item 5 (I seek assistance when facing learning problems) and item 13 (I have motivation to learn). The items with the lowest means are: item 10 [I am not distracted by other online activities when learning online (instant messages, Internet surfing)], item 1 (I feel confident in performing the basic functions of Microsoft), item 16 (I feel confident in using online tools (email, discussion) to effectively communicate with others), item 11 (I repeated the online instructional materials on the basis of my needs) and item 2 (I feel confident in my knowledge and skills of how to manage software for online learning). 


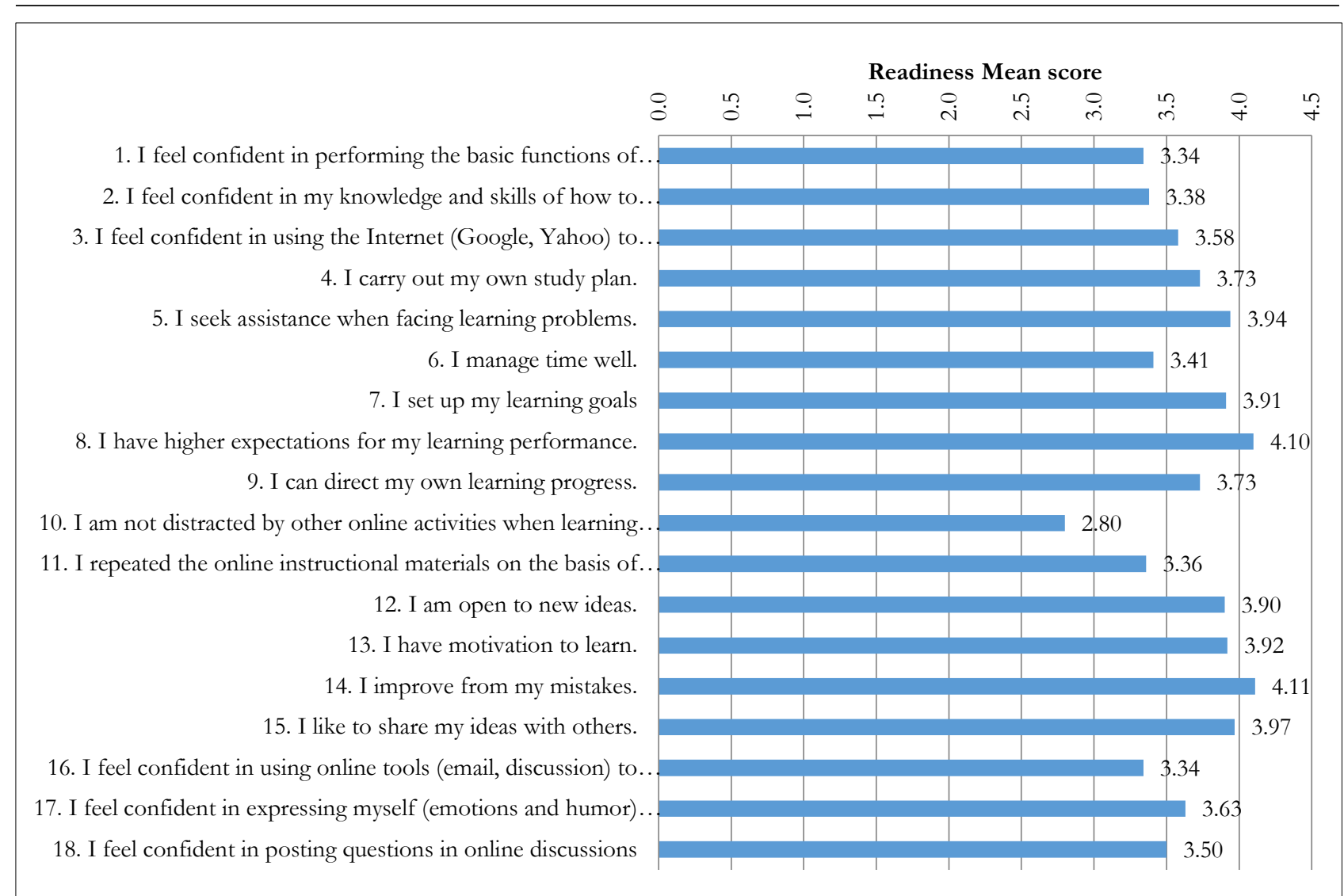

Figure 1. Mean scores of items of the OLRS

\section{DIFFERENCES IN READINESS BY GENDER}

Table 4. Independent samples t-test of online learning readiness scores by gender

\begin{tabular}{lllllcc}
\hline Dimensions & Sex & N & M & SD & $t$ & $p$ \\
\hline \multirow{2}{*}{ Online Learning Readiness score (OLRS) } & Male & 66 & 3.71 & 0.82 & \multirow{2}{*}{0.94} & \multirow{2}{*}{$0.349^{*}$} \\
\hline \multirow{2}{*}{ Computer/Internet Self-efficacy (CIS) } & Female & 49 & 3.57 & 0.76 & \multirow{2}{*}{0.161} & \multirow{2}{*}{$0.162^{*}$} \\
\hline \multirow{2}{*}{ Self-Directed Learning (SDL) } & Male & 66 & 3.57 & 1.14 & \multirow{2}{*}{$0.453^{*}$} \\
\hline \multirow{2}{*}{ Learner Control (LC) } & Female & 49 & 3.26 & 1.18 & \multirow{2}{*}{0.75} & \multirow{2}{*}{$0.03^{* *}$} \\
\hline \multirow{2}{*}{ Motivation for Learning (ML) } & Male & 66 & 3.88 & 0.96 & \multirow{2}{*}{2.19} \\
\multirow{2}{*}{ Online communication self-efficacy (OCS) } & Female & 49 & 3.74 & 0.90 & \multirow{2}{*}{$0.913^{*}$} \\
\hline
\end{tabular}

** Significant $(p<.05) \quad{ }^{*}$ Not significant $(p>.05)$

Independent samples t-test was performed to determine if any significant differences exist between readiness of males and females. Table 4 shows the results of the independent samples t-test. There was no significant difference in online learning readiness between males $(\mathrm{M}=3.71, \mathrm{SD}=.82)$ and females $(\mathrm{M}=3.57, \mathrm{SD}=.76), \mathrm{t}$ $(.94) p=.349$. There was no significant difference between males and females in all dimensions except for learner control. The results revealed a significant difference in learner control (LC) between males $(\mathrm{M}=3.47, \mathrm{SD}=.94)$ and females $(\mathrm{M}=3.06, \mathrm{SD}=1.05), \mathrm{t}(2.19) p=.03$. 


\section{DIFFERENCES IN READINESS BY COURSE LEVEL}

Table 5. Independent samples t-test of online learning readiness scores by course level

\begin{tabular}{|c|c|c|c|c|c|c|}
\hline Dimensions & Course level & $\mathbf{N}$ & $\mathbf{M}$ & SD & $t$ & $p$ \\
\hline \multirow{2}{*}{ Online Learning Readiness score (OLRS) } & Level 100 & 106 & 3.65 & 0.79 & \multirow{2}{*}{-0.122} & \multirow{2}{*}{$0.903^{*}$} \\
\hline & Level 200 & 9 & 3.68 & 0.85 & & \\
\hline \multirow{2}{*}{ Computer/Internet Self-efficacy (CIS) } & Level 100 & 106 & 3.43 & 1.15 & \multirow{2}{*}{-0.224} & \multirow{2}{*}{$0.823^{*}$} \\
\hline & Level 200 & 9 & 3.52 & 1.31 & & \\
\hline \multirow{2}{*}{ Self-Directed Learning (SDL) } & Level 100 & 106 & 3.83 & 0.94 & \multirow{2}{*}{0.509} & \multirow{2}{*}{$0.612^{*}$} \\
\hline & Level 200 & 9 & 3.67 & 0.93 & & \\
\hline \multirow{2}{*}{ Learner Control (LC) } & Level 100 & 106 & 3.28 & 1.00 & \multirow{2}{*}{-0.577} & \multirow{2}{*}{$0.565^{*}$} \\
\hline & Level 200 & 9 & 3.48 & 1.09 & & \\
\hline \multirow{2}{*}{ Motivation for Learning (ML) } & Level 100 & 106 & 3.96 & 0.92 & \multirow{2}{*}{-0.473} & \multirow{2}{*}{$0.637 *$} \\
\hline & Level 200 & 9 & 4.11 & 0.77 & & \\
\hline \multirow{2}{*}{ Online communication self-efficacy (OCS) } & Level 100 & 106 & 3.49 & 1.08 & \multirow{2}{*}{0.032} & \multirow{2}{*}{$0.975^{*}$} \\
\hline & Level 200 & 9 & 3.48 & 1.43 & & \\
\hline
\end{tabular}

*Not significant $(p>.05)$

Independent samples t-test was performed to determine if any significant difference exits in readiness by course level. Table 5 shows the results of the independent samples t-test. It was found that there was no significant difference in readiness between level 100 students $(\mathrm{M}=3.65, \mathrm{SD}=.79)$ and level 200 students $(\mathrm{M}=3.68, \mathrm{SD}=$ .85) $\mathrm{t}(-.122) \mathrm{p}=.903$. For all the dimensions of the scale, there was no significant difference in readiness between level 100 and level 200 students.

\section{DISCUSSION}

\section{Pre-service teachers' readiness for online learning}

The first research question sought to determine pre-service teachers' online learning readiness. The study found that pre-service teachers' overall readiness for online learning was higher than average $(\mathrm{M}=3.65, \mathrm{SD}=.79)$. The readiness scores for the five dimensions ranged from 3.30 to 3.97. The dimension with the highest mean scores was motivation for learning (ML) $[\mathrm{M}=3.97, \mathrm{SD}=.90]$ followed by self-directed learning (SDL) $[\mathrm{M}=3.82, \mathrm{SD}=$ .93]. However, the dimensions of learner control $(\mathrm{M}=3.30, \mathrm{SD}=1.00)$, computer/internet self-efficacy $(\mathrm{M}=$ $3.43, \mathrm{SD}=1.16)$ and online communication self-efficacy $(\mathrm{M}=3.49, \mathrm{SD}=1.11)$ recorded low means.

The findings agrees with others for example, Cigdem and Yildirim (2014) used Hung et al.'s Online Learning Readiness Scale (OLRS) in their study reported that readiness mean scores were between 3.564 and 4.455 over the mid-point indicating that the participants were in generally ready for online learning. They found that participants had the highest readiness in the dimension of ML, followed by SDL and LC, and the lowest readiness in the dimensions of OCS and CIS. Cigdem and Ozturk (2016) reported that students' motivation for learning $(\mathrm{M}=$ 4.15) is higher than both their computer self-efficacy $(\mathrm{M}=3.55)$ and their self-directed learning inclinations $(\mathrm{M}=$ 3.82). Hung et al (2010) found that students' levels of readiness were high in computer/Internet self-efficacy, motivation for learning, and online communication self-efficacy and were low in learner control and self-directed learning. Kayaoğlu and Akbaş (2016), reported that, except for the computer and internet self-efficacy issue, the other factors referring to the online learning motivation, online communication self-efficacy, self-directed learning and learner control in an online context appear to be higher than 3.50. The overall results reveal that the participants seem to be ready for an online learning adoption. They added that students need to improve their computer and internet self-efficacy. Kirmiz1 (2015), in a study to investigate the relation between learning readiness and student satisfaction at higher education, found that participants have a high level of learner readiness and satisfaction. The dimensions of readiness were computer self-efficacy, self-directed learning, learner control, motivation, and online self-efficacy.

Rasouli, Rahbania and Attaran (2016) in their study to investigate students' readiness for e-learning application in higher education, found that the readiness mean score of students studied in 5 factors was 3.54 out of 5 . This indicated that the average readiness of art students to participate in e-learning was high. Yağc1, Strakaya and Özüdoğru (2015) also reported that readiness of pre-service teachers toward web-based teaching was found in the range between median and high levels. However, Stokes, Cannavina, and Cannavina (2004) in a study of readiness levels of medical school students for web-based learning environments found no sufficient readiness level.

\section{Online learning readiness of males and females}

The study found no significant difference in online learning readiness between males and females. Hung et al (2010) also found that gender made no statistical differences in the five OLRS dimensions, but that higher grade 
(junior and senior) students exhibited significantly greater readiness in the dimensions of self-directed learning, online communication self-efficacy, motivation for learning, and learner control than did lower grade (freshman and sophomore) students. Yağc1, Sırakaya and Özüdoğru (2015) also found no significant difference in the readiness levels of female and male pre-service teachers toward web-based teaching.

\section{Online learning readiness by course level}

The study found no significant difference in readiness between level 100 and level 200 students. Yağc1, Sirakaya and Özüdoğru (2015) also found no significant difference in readiness at the grade level. However, Hung and et al (2010) reported that there was significant difference in online learning readiness levels of students according to their grade level. Hung et al. added that students' maturity may play an important role in their monitoring, managing, control, and motivation relative to online learning.

\section{CONCLUSION}

The findings of the study revealed that pre-service teachers' readiness for online learning is high. However, they recorded low readiness in dimensions of learner control, computer/internet self-efficacy, and online communication self-efficacy. Students need to be encouraged to take control of their learning. Studies have shown that the sense of control learners' gain while interacting with instructional media and content can result in increased satisfaction, enjoyment, and confidence. The nature of online learning makes it possible to provide learners with the opportunity to take charge of their learning pace, sequence, and content.

Also, students need to improve on their computer and internet self-efficacies. Teachers need to encourage students, especially those with lower self-efficacy in online communication, to participate in the discussions, ask questions, post ideas and their thoughts, and to seek assistance when facing problems online. Teachers could also stimulate peer assistance among students. Hung et al (2010) suggested that teachers can provide students with an appropriate induction into the world of online learning by having students get to know their teacher or peers through online tools and by responding promptly and positively to students' inquiries through online tools. Computer self-efficacy is mainly related to learners' confidence in their ability to use computers and other type of technology. Studies have found that computer self-efficacy has a positive relationship with students' cognitive and emotional engagement factors and suggested that computer self-efficacy is a very important and critical factor to student satisfaction with e-learning. Teachers can persuade and encourage students to increase their computer and internet self-efficacies.

\section{REFERENCES}

Alem, F., Plaisent, M., Zuccaro, C., \& Bernard, P. (2016). Measuring e-Learning Readiness Concept: Scale Development and Validation Using Structural Equation Modeling. International Journal of e-Education, e-Business, e-Management and e-Learning, 6(4), 193-207. https:// doi.org/10.17706/ijeeee.2016.6.4.193-207

Artino, A. R., Jr., \& Stephens, J. M. (2009). Beyond grades in online learning: Adaptive profiles of academic selfregulation among Naval Academy undergraduates. Journal of Advanced Academics, 20(4), 568-601. https:// doi.org/10.1177/1932202X0902000402

Bandura, A. (1977a). Self-efficacy: Toward a unifying theory of behavioral change. Psychological Review, 84(2), 191215. https:// doi.org/10.1037/0033-295X.84.2.191

Basol, G., Cigdem, H., \& Unver, T. K. (2018). Variables Explaining the Online Learning Readiness Level of Students: Turkish Vocational College Example. European Journal of Education Studies, 4(10), 14-32. https:// doi.org/10.5281/zenodo.1302956

Bell, B. S., \& Federman, J. E. (2013). E-learning in postsecondary education. The Future of Children, 23(1), 165-185. https://doi.org/10.1353/foc.2013.0007

Blidi, S. (2017). Collaborative learner autonomy: A model of learner autonomy development. Oman: Springer. https://doi.org/10.1007/978-981-10-2048-3

Borotis, S., \& Poulymenakou, A. (2004). E-Learning Readiness Components: Key Issues to Consider Before Adopting e-Learning Interventions. Paper presented at the E-Learn: World Conference on E-Learning in Corporate, Government, Healthcare, and Higher Education 2004, Washington, DC, USA. https://www.learntechlib.org/p/11555

Bozkurt, A., \& Sharma, R. C. (2020). Emergency remote teaching in a time of global crisis due to CoronaVirus pandemic. Asian Journal of Distance Education, 15(1). https://doi.org/10.5281/zenodo.3778083 
Budzar, M. A., Ali, A., \& Tariq, R. U. H. (2016). Emotional Intelligence as a Determinant of Readiness for Online Learning. The International Review of Research in Open and Distributed Learning, 17(1). https://doi.org/10.19173/irrodl.v17i1.2149

Chorrojprasert, L. (2020). Learner Readiness - Why and How Should They Be Ready? Language Education and Acquisition Research Network Journal, 13(1), 268-274.

Cigdem, H., \& Ozturk, M. (2016). Critical Components of Online Learning Readiness and Their Relationships with Learner Achievement. Turkish Online Journal of Distance Education-TOJDE, 17(2), 98-109. https://doi.org/10.17718/tojde.09105

Cigdem, H., \& Yildirim, O. G. (2014). Effects of Students' Characteristics on Online Learning Readiness: A Vocational College Example. Turkish Online Journal of Distance Education, 15(3), 80-93. https://doi.org/10.17718/tojde.69439

Conley, D. T. (2007). Toward a more comprehensive conception of college readiness. Eugene, OR: Educational.

Conley, D. T., \& French, E. M. (2013). Student Ownership of Learning as a Key Component of College Readiness. American Behavioral Scientist, 58(8), 1018-1034. https://doi.org/10.1177/0002764213515232

Dangol, R., \& Shrestha, M. (2019). Learning Readiness and Educational Achievement among School Students. The International Journal of Indian Psychology, 7(2). https:/ / doi.org/10.25215/0702.056

Deyo, Z. M., Huynh, D., Rochester, C., Sturpe, D. A., \& Kiser, K. (2011). Readiness for selfdirected learning and academic performance in an ability laboratory course. American Journal of Pharmaceutical Education, 75(2), 1-6. https://doi.org/10.5688/ajpe75225

Dhawan, S. (2020). Online Learning: A Panacea in the Time of COVID-19 Crisis. Journal of Educational Technology Systems. https://doi.org/10.1177/0047239520934018

Dray, B. J., Lowenthal, P. R., Miszkiewicz, M. J., Ruiz-Primo, M. A., \& Marczynski, K. (2011). Developing an instrument to assess student readiness for online learning: a validation study. Distance Education, 32(1), 29-47. https://doi.org/10.1080/01587919.2011.565496

Edwards, F. R. (2018). The Relationship Between College Student Attitudes Towards Online Learning Based on Reading SelfEfficacy, Ethnicity, And Age. (Doctor of Education), Liberty University.

Engin, M. (2017). Analysis of Students' Online Learning Readiness Based on Their Emotional Intelligence Level. Universal Journal of Educational Research, 5(12A), 32-40. https://doi.org/10.13189/ujer.2017.051306

Garrison, D. R. (2011). E-Learning in the 21st Century: A framework, for research and practice, 2nd ed: NY, Routledge.

Guglielmino, P. \& Guglielmino, L. (2003). Are your learners ready for e-learning? In G. Piskurich (Ed.), The $A M A$ bandbook of e-learning. New York: American Management Association.

Hall, J. (2008). Cross-Sectional Survey Design. In P. J. Lavrakas (Ed.), Encyclopedia of Survey Research Methods: Sage Publications, Inc. https:// doi.org/10.4135/9781412963947

Horzum, M. B., Kaymak, Z. D., \& Gungoren, O. C. (2015). Structural Equation Modeling Towards Online Learning Readiness, Academic Motivations, and Perceived Learning. Educational Sciences: Theory \& Practice. https://doi.org/10.12738/estp.2015.3.2410

Hung, M.-L., Chou, C., Chen, C.-H., \& Own, Z.-Y. (2010). Learner readiness for online learning: Scale development and student perceptions. Computers \& Education, 55(3), 1080-1090. https://doi.org/10.1016/j.compedu.2010.05.004

Kartal, G., \& Balcikanli, C. (2019). Tracking the culture of learning and readiness for learner autonomy in a Turkish context. TEFLIN Journal, 30(1), 22-46. https:// doi.org/10.15639/teflinjournal.v30i1/22-46

Kayaoğlu, M. N., \& Akbaş, R. D. (2016). Online Learning Readiness: A Case Study in the Field of English for Medical Purposes. Participatory Educational Research (PER), 4, 212-220.

Keramati, A., Afshari-Mofrad, M. \& Kamran, A. (2011). The role of readiness factors in Elearning outcomes: An empirical study. Computers \& Education, 57, 1919-1929. https://doi.org/10.1016/j.compedu.2011.04.005

Kırmızi, Ö. (2015). The Influence of Learner Readiness on Student Satisfaction and Academic Achievement in an Online Program at Higher Education. The Turkish Online Journal of Educational Technology, 14(1), 133-142.

Knowles, M. S. (1975). Self-directed learning: A guide for learners and teachers. New York: Association Press.

Lee, O., \& Campbell, T. (2020). What Science and STEM Teachers Can Learn from COVID-19: Harnessing Data Science and Computer Science through the Convergence of Multiple STEM Subjects. Journal of Science Teacher Education, 31(8), 932-944. https://doi.org/10.1080/1046560x.2020.1814980

Leung, J. T.-y., \& Shek, D. T.-1. (2018). Quantitative Research Methods. In B. B. Frey (Ed.), The SAGE Encyclopedia of Educational Research, Measurement, and Evaluation: SAGE Publications, Inc. https://doi.org/10.4135/9781506326139

Liu, J. C. (2019). Evaluating Online Learning Orientation Design with a Readiness Scale. Online Learning, 23(4). https://doi.org/10.24059/olj.v23i4.2078 
Liu, J. C., \& Roberts-Kaye, E. (2016). Preparing online learning readiness with learner-content interaction: Design for scaffolding self-regulated learning. In L. Kyei-Blankson, J. Blankson, E. Ntuli, and C. Agyeman (Eds.), Handbook of research on strategic management of interaction, presence and participation in online courses (pp. 216-243). Hershey, PA: IGI Global.

Lynch, M. M. V. (2001). How to Be a Successful Distance Learning Student: Learning on the Internet. New York: Pearson Custom Publishing.

McVay, M. (2001). How to be a successful distance education student: Learning on the Internet. New York: Prentice Hall.

Milheim, W. D., \& Martin, B. L. (1991). Theoretical bases for the use of learner control: Three different perspectives. Journal of Computer-Based Instruction, 18(3), 99-105.

Moore, J., Dickson-Deane, C., \& Galyen, K. (2011). e-Learning, online learning, and distance learning environments: Are they the same? Internet and Higher Education, 14(1), 129135. https://doi.org/10.1016/j.iheduc.2010.10.001

Morris, L., Wu, S., \& Finnegan, C. (2005). Predicting retention in online general education courses. The American Journal of Distance Education, 19(1), 23-36. https://doi.org/10.1207/s15389286ajde1901_3

Morrison, D. (2003). E-learning strategies: how to get implementation and delivery right first time. Chichester, Jhon Wiley \& Sons.

Pajares, F. (2002). Gender and perceived self-efficacy in self-regulated learning. Theory into Practice, 41(2), 116-125. https://doi.org/10.1207/s15430421tip4102_8

Peng, H., Tsai, C.-C, \& Wu, Y.-T. (2006). University students' selfefficacy and their attitudes toward the Internet: the role of students' perceptions of the Internet. Educational Studies, 32(1), 73-86. https://doi.org/10.1080/03055690500416025

Potts, J. A., \& Potts, S. (2017). Is Your Gifted Child Ready for Online Learning? Gifted Child Today, 40(4), 226-231. https://doi.org/10.1177/1076217517722182

Prakash, J. (2012). Brief notes on the Thorndike's Laws of Learning. Preserve articles, Retrieved from http://www.preservearticles.com/201105206859/throndikes-laws-oflearning.html

Rasouli, A., Rahbania, Z., \& Attaran, M. (2016). Students' Readiness for E-learning Application in Higher Education. Malaysian Online Joumal of Educational Technology, 4(3), 51-64.

Ryan, R. M., \& Deci, E. L. (2000). Intrinsic and extrinsic motivations: classic definitions and new directions. Contemporary Educational Psychology, 25(1), 54-67. https://doi.org/10.1006/ceps.1999.1020

Sangrà, A., Vlachopoulos, D., Cabrera, N., \& Bravo, S. (2011). Towards an inclusive definition of e-learning. Barcelona, Spain: eLearn Center.

Shyu, H. Y. \& Brown, S. W. (1992). Learner control versus program control in interactive videodisc instruction: what are the effects in procedural learning? International Journal of Instructional Media, 19(2), 85-95.

Smith, P. J., Murphy, K. L., \& Mahoney, S. E. (2003). Towards identifying factors underlying readiness for online learning: An exploratory study. Distance Education, 24(1), 57-67. https://doi.org/10.1080/01587910303043

Stokes, C. W., Cannavina, C., \& Cannavina, G. (2016). The state of readiness of student health professionals for web-based learning environments. Health Informatics Journal, 10(3), 195-204. https://doi.org/10.1177/1460458204045434

Swan, K. (2004). Learning online: A review of current research on issues of interface, teaching presence and learner characteristics. Paper presented at the Elements of Quality Online Education, Needham, MA.

Taipjutorus, W., Hansen, S., \& Brown, M. (2012). Investigating a Relationship between Learner Control and Selfefficacy in an Online Learning Environment. Journal of Open, Flexible, and Distance Learning, 16(1), 56-69.

Tang, S. F. \& Lim, C. L. (2013). Undergraduate Students' Readiness in E-Learning: A Study at the Business School in a Malaysian Private University. International Journal of Management \& Information Technology, 4(2). 198-204. https://doi.org/10.24297/ijmit.v4i2.1900

Tsai, M. J., \& Tsai, C. C. (2003). Information searching strategies in web-based science learning: the role of Internet self-efficacy. Innovations in Education and Teaching International, 40(1), 43-50. https://doi.org/10.1080/1355800032000038822

Warner, D., Christie, G. \& Choy, S. (1998). Readiness of VET clients for flexible delivery including on-line learning. Brisbane: Australian National Training Authority.

Wolters, C. A. (2010). Self-regulated learning and the 21st century competencies. Retrieved from: http://www.hewlett.org/uploads/Self_Regulated_Learning_21st_Century_Compe tencies.pdf

Yağc1, M., Sırakaya, D. A., \& Özüdoğru, G. (2015). The Investigation of Attitude and Readiness of Information and Communication Technologies Pre-service Teachers Toward Web Based Learning. Procedia - Social and Behavioral Sciences, 174, 1099-1106. https://doi.org/10.1016/j.sbspro.2015.01.800 